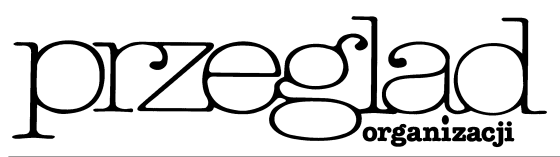

\title{
Ośrodki odpowiedzialności w jednostkach gospodarczych - nowoczesne narzędzie zarządzania
}

https://doi.org/10.33141/po.2005.11.08

\section{Magdalena Ossowska}

Przegląd Organizacji, Nr 11 (790), 2005, ss. 29-32 www.przegladorganizacji.pl Towarzystwo Naukowe Organizacji i Kierownictwa (TNOiK)
Zapewnienie sprawności i skuteczności w działaniu każdego przedsiębiorstwa działającego na globalnym rynku wymaga umiejętnego dostosowania swojej struktury organizacyjnej do potrzeb prowadzonej działalności. Taka struktura w całej swojej istocie powinna przyczyniać się w szczególności do zwiększania skuteczności zarządzania jednostką, co powinno mieć swoje konsekwencje w poprawie efektywności działania, umiejętności sprostania wymaganiom stawianym przez klientów, a także sprawności w dostosowywaniu się do wymogów konkurencyjnego rynku.

Jednym z kierunków zwiększenia skuteczności zarządzania przedsiębiorstwem jest decentralizacja ich systemów zarządzania. Decentralizacja zarządzania zorientowana jest przede wszystkim na decentralizację funkcji operacyjnych. Polega ona na wyodrębnieniu w ramach jednego przedsiębiorstwa wielu jednostek i przekazaniu (delegowaniu) uprawnień decyzyjnych na niższe szczeble zarządzania oraz na zwiększeniu samodzielności jednostek organizacyjnych szczebla niższego. Dzięki takiej dystrybucji uprawnień stworzone zostają warunki niezbędne do szybszego dostosowania się do zmienności otoczenia i lokalnych uwarunkowań ${ }^{11}$.

Jedną z form decentralizacji jest wyodrębnienie w przedsiębiorstwie jednostek nazywanych ośrodkami odpowiedzialności lub centrami odpowiedzialności.

Ośrodek odpowiedzialności to segment (fragment) obszaru funkcjonowania organizacji lub we- wnętrzna jednostka organizacyjna, najczęściej zarządzana w sposób jednoosobowy, której kierownik jest odpowiedzialny za realizację celu wyznaczonego przez kierownictwo wyższego poziomu zarządzania. Należą do nich jednostki wyodrębniane wewnątrz firmy, takie jak: wydział, zakład, fabryka, filia lub obszar działalności, np. działalność produkcyjna, handlowa, usługowa ${ }^{2}$.

Przy podziale przedsiębiorstwa na ośrodki odpowiedzialności są stosowane różne kryteria ich wyodrębniania. Najczęściej stosowane kryteria wydzielania centrów odpowiedzialności przedstawia tabela.

Ze względu na zakres odpowiedzialności, autonomię działania oraz sposób pomiaru wykonania zadań finansowych w organizacjach zdecentralizowanych wyróżnia się pięć typów ośrodków odpowiedzialności, a mianowicie: ${ }^{3)}$

- ośrodki odpowiedzialności za koszty,

- ośrodki odpowiedzialności za limit wydatków,

- ośrodki odpowiedzialności za przychody,

- ośrodki odpowiedzialności za zysk,

- ośrodki odpowiedzialności za inwestowanie.

Ośrodki odpowiedzialności za koszty najczęściej pokrywają się z wydziałami produkcyjnymi, ale mogą również stanowić: działy, oddziały, grupy robót, brygady itp. Kierownik może wpływać tylko na poziom kosztów związanych z realizowaną działalnością i musi posiadać swobode podejmowania w tym zakresie decyzji. Powinien otrzymywać wszelkie informacje niezbędne do podejmowania decyzji i kontroli ich

Tab. Kryteria wydzielania ośrodków odpowiedzialności

\begin{tabular}{|c|l|}
\hline Kryterium & \multicolumn{1}{|c|}{ Charakterystyka } \\
\hline terytorialne & $\begin{array}{l}\text { Ośrodek powinien obejmować wyodrębniony teren działania (budynek, powierzchnia w budynku lub } \\
\text { hali produkcyjnej, osobny obszar). }\end{array}$ \\
\hline organizacyjne & $\begin{array}{l}\text { Ośrodek stanowi element składowy struktury organizacyjnej jednostki z osobą wyznaczoną do kierowa- } \\
\text { nia. }\end{array}$ \\
\hline informacyjne & $\begin{array}{l}\text { Dokumenty źródłowe o ponoszonych kosztach i osiąganych przychodach w ośrodku są ewidencjonowa- } \\
\text { ne na osobnych kontach analitycznych, a informacje o nich są dostępne dla danego kierownika. }\end{array}$ \\
\hline przedmiotowe & $\begin{array}{l}\text { Realizowane w podmiocie działania lub procesy stanowią pod względem technologicznym cykle zamknięte } \\
\text { w obszarze ośrodka odpowiedzialności, a ich efektem jest produkt finalny, półfabrykat, usługa zewnętrzna, } \\
\text { świadczenie wewnętrzne. }\end{array}$ \\
\hline decyzyjne & $\begin{array}{l}\text { Określony jest zakres swobody decyzyjnej kierownika podmiotu, co determinuje rodzaj ośrodka odpo- } \\
\text { wiedzialności. }\end{array}$ \\
\hline
\end{tabular}

Źródło: opracowanie własne na podstawie: Rachunkowość zarzadcza. Wybrane zagadnienia, testy i zadania, red. E. Walińska, P. Urbanek. Fundacja Rozwoju Rachunkowości w Polsce, Łódź 2000, s. 127; Rachunek kosztów i rachunkowość zarządcza..., op.cit., s. 112 . 
realizacji oraz wyznaczonego poziomu kosztów. Kierownictwo tego ośrodka nie kontroluje wysokości osiąganych przychodów ze sprzedaży efektów pracy przedsiębiorstwa, tym bardziej wyników finansowych, ani nie podejmuje decyzji powodujacych zmiany w posiadanych zasobach danego ośrodka czy całej jednostki. Ośrodki odpowiedzialności za koszty są stosunkowo łatwe do wyodrębnienia, jednak ich tworzenie nie może być mechanicznym zabiegiem administracyjnym, utrwalającym dotychczasowy podział przedsiębiorstwa na komórki organizacyjne. Każdorazowo powinna być przeprowadzona dogłębna analiza warunków działania, połączona z weryfikacją zakresu rozdysponowanych już wcześniej obowiązków, uprawnień i odpowiedzialności. W tworzeniu centrów kosztowych mogą wystąpić pewne ograniczenia, zarówno o charakterze indywidualnym, właściwym dla danego przedsiębiorstwa, jak i ogólnym. Dlatego też, przy tworzeniu ośrodka kosztów należy zapewnićc):

- możliwość planowania kosztów ze szczegółowością, z jaka wydzielono centra kosztowe;

- możliwość jednoznacznego przypisania poniesionych kosztów do wyodrębnionego ośrodka;

- objęcie zakresem odpowiedzialności przedmiotowo wydzielonego takiego segmentu działalności, aby można było dokonać identyfikacji i pomiaru stanów na jego styku z otoczeniem zewnętrznym i wewnętrznym („wejście” i „wyjście”);

- dostosowanie zasad pomiaru stanów „wejść" i „wyjśćc" do zakresu swobody decyzyjnej i odpowiedzialności danego ośrodka oraz związanych z tym mierników oceny.

Jeżeli nie zostaną spełnione wszystkie wymagania, wówczas każda próba uczynienia z takiego centrum sprawnie działającego ośrodka odpowiedzialności nie zakończy się spodziewanym rezultatem.

Pod kontrolą tego ośrodka odpowiedzialności znajdują się ponoszone koszty. Jednak przy dokonywaniu oceny działań kierownika ośrodka ważne jest rozróżnienie dwóch kategorii kosztów ponoszonych przez dany ośrodek, a mianowicie kosztów kontrolowanych i kosztów nie kontrolowanych ${ }^{5}$. Koszty kontrolowane to koszty, które kształtują się pod wpływem decyzji kierownika ośrodka, są od niego zależne. Natomiast koszty nie kontrolowane ponoszone są w związku z działalnością ośrodka, jednak na ich kształtowanie kierownik nie ma wpływu. Maja one jedynie charakter informacyjny i nie sa wykorzystywane w ocenie dokonań ośrodka. Zatem dla prawidłowej oceny działań kierownictwa ośrodka odpowiedzialności kosztów, powinny być one poprawnie wyodrębnione.

Ocena ośrodków odpowiedzialności za koszty odbywa się poprzez porównanie kosztów rzeczywistych z kosztami planowanymi. Kryterium oceny dokonań centrum kosztów jest odchylenie kosztów rzeczywistych od kosztów planowanych (koszty planowane koszty rzeczywiste = odchylenie kosztów), które poddawane jest szczegółowej analizie ${ }^{6)}$.

Ośrodki odpowiedzialności za limit wydatków są to takie komórki przedsiębiorstwa, w których nie ma wyraźnej zależności między działalnością a jej kosztami, w związku z czym ocena poziomu kosztów jest bardzo subiektywna. Limit wydatków wynika zazwyczaj z negocjacji lub też jest narzucany. Przekro- czenie jednak określonego limitu nie zawsze świadczy na niekorzyść ośrodka i nie jest wynikiem niegospodarności. Dlatego też konieczne jest stosowanie dodatkowych miar oceny, często niefinansowych. Dotyczy to głównie komórek administracji i zarządu, a także ogólnoprodukcyjnych ${ }^{7)}$.

Ośrodki odpowiedzialności za przychody są to wewnętrzne podmioty, których kierownicy sa odpowiedzialni, a także rozliczani, za poziom osiąniętego przychodu w danym okresie. Są to najczęściej podmioty zajmujące się marketingiem i sprzedażą produktów. Od nich w dużym stopniu zależą rozmiary i struktura sprzedaży, jak również cena sprzedaży. W ośrodkach tych mogą być wyodrębniane obiekty przychodów uporządkowane hierarchicznie, jak na przykład: grupa produktowa, obszar rynku, kanał dystrybucji, klienci indywidualni lub grupa klientów czy stanowisko sprzedaży. Ich ranga jest znacząca $\mathrm{z}$ uwagi na istotną rolę przychodów ze sprzedaży w całej działalności jednostki gospodarczeje).

Ośrodki odpowiedzialności za zysk, lub inaczej za wyniki finansowe, są to podmioty, których kierownictwo dysponuje znaczącym zakresem uprawnień i odpowiedzialności. Pod ich kontrolą znajdują się ponoszone koszty i osiagane przychody, a w ostatecznym rezultacie wyniki finansowe, w szczególności zaś zyski. Dlatego też kierownictwo odpowiedzialności za zyski oceniane jest na podstawie odchyleń kwoty zysku rzeczywiście osiagniętego od zysku planowanego.

Aby można było jednak mówić o odpowiedzialności jednostki za wygenerowane przychody ze sprzedaży efektów jej pracy, muszą zostać spełnione następujące warunki ${ }^{9)}$.

- W gestii kierownictwa jednostki leży decyzja, jakie wyroby czy usługi będą produkowane w danym okresie. Ma to szczególne znaczenie w przypadku wykorzystywania do produkcji zapasów, którymi przedsiębiorstwo dysponuje w ograniczonej ilości, a mogą one zostać zużyte w produkcji mniej lub bardziej rentownych produktów.

- Jednostka decyduje o poziomie ceny, kierunkach sprzedaży, w przypadku kiedy ceny dyktuje rynek, i tym samym może wybierać rynki, na których realizowana jest największa marża, a także o wysokości i kryteriach udzielania rabatów i upustów.

- Produkt będący przedmiotem sprzedaży jest:

- w całości wytwarzany w jednostce produkcyjnej,

- wytwarzany etapowo w kilku jednostkach, przy czym tylko jednostka realizująca ostatni etap produkcyjny stanowi centrum zysku, natomiast pozostałe centra kosztów,

- wytwarzany etapowo w kilku jednostkach będących centrami zysku i obowiązuje w przedsiębiorstwie system cen wewnętrznych negocjowanych lub opartych na cenach rynkowych.

Głównym motywem wprowadzenia w przedsiębiorstwie centrów zysku jest dążenie do maksymalizacji zysku osiąganego przez jednostkę. Oznacza to, że przy wprowadzeniu centrów zysku jako kryterium optymalizacji decyzji ekonomicznych podejmowanych przez poszczególne ośrodki odpowiedzialności występuje zysk. W ośrodkach zysku będzie więc miało miejsce optymalizowanie takich wielkości ekonomicznych, które wiążą się z osiąganiem przez te centra zysku. 
Ośrodki odpowiedzialności za zysk to najczęściej zakłady w przedsiębiorstwie wielooddziałowym. Centrami zysku mogą być również wydziały produkcji podstawowej czy produkcji pomocniczej, które moga jednak decydować o sprzedaży swoich produktów ${ }^{10)}$.

Ośrodki odpowiedzialności za inwestowanie są to wewnętrzne jednostki organizacyjne, którym przydzielony został największy zakres decyzyjny i odpowiedzialności. W ramach wyznaczonej, przez generalne kierownictwo firmy, swobody decyzyjnej, w gestii kierownika ośrodka leży sterowanie poziomem kosztów i przychodów, kontrola procesów produkcji i sprzedaży, dokonywanie zmian w zdolnościach produkcyjnych firmy oraz odpowiednie wykorzystanie posiadanych funduszy inwestycyjnych.

Ośrodki odpowiedzialności za inwestowanie wprowadza się zazwyczaj w dużych przedsiębiorstwach o złożonej strukturze organizacyjnej, w przedsiębiorstwach wielooddziałowych, gdzie takim ośrodkiem moga być poszczególne oddziały przedsiębiorstwa (konglomeratu).

Główną przesłanką wprowadzenia w przedsiębiorstwie ośrodków odpowiedzialności za inwestowanie jest maksymalizacja zwrotu zainwestowanego kapitału. Kierownicy tych centrów ponoszą odpowiedzialność za podjęte decyzje o charakterze inwestycyjnym, a więc są rozliczani z kształtowania się relacji miedzy dochodem osiągniętym przez ośrodek a wysokością zainwestowanych w jego działalność kapitałów ${ }^{11)}$.

Ośrodki te zostały uporządkowane według zakresu samodzielnie podejmowanych decyzji w kolejności - od najmniejszego do największego. Najmniejszy zakres odpowiedzialności mają działy odpowiedzialne za koszty, natomiast najszerszy zakres odpowiedzialności przypisany jest do centrów inwestycji, a zatem do zarządu czy akcjonariuszy przedsiębiorstwa. Hierarchia odpowiedzialności każdego ośrodka odpowiedzialności została przedstawiona na rysunku.

Hierarchiczna struktura ośrodków odpowiedzialności charakteryzuje się wzrastającym zakresem odpowiedzialności w miarę przechodzenia na coraz wyższy poziom. Wzrost odpowiedzialności powinien być proporcjonalny do zakresu przyznanych kompetencji, zaś uprawnienia decyzyjne kierowników ośrodków powinny być tak zwiększone, aby mieli oni rzeczywisty wpływ na funkcjonowanie komórek, którymi zarządzają. Tylko wtedy egzekwowanie odpowiedzialności może być skuteczne. Równocześnie konieczne jest rozgraniczenie kompetencji poszczególnych ośrodków odpowiedzialności tak, aby wyeliminowane zostały zjawiska krzyżowania się niekiedy sprzecznych interesów kierowników i powstających z tego tytułu niejasności w procesie funkcjonowania przedsiębiorstwa. Nie można bowiem przypisywać kierownikom komórek organizacyjnych określonych zakresów odpowiedzialności, jeżeli realizacja przydzielonych im zadań w dużej mierze zależy od decyzji podejmowanych w innych komórkach ${ }^{12)}$.

W związku z tym, że największym zakresem odpowiedzialności $\mathrm{z}$ reguły obarczane jest kierownictwo ośrodków odpowiedzialności za zysk, osiągane przychody i ponoszone koszty jednostek wewnętrznych powinny być kształtowane w taki sposób, aby kwota płaconego podatku dochodowego była dla organizacji jak najmniejsza. Ważnym czynnikiem staje się również racjonalnie wypracowana długookresowa polityka stabilizujacca procesy zbytu, zaopatrzenia, zapewnienia dostaw czynników wytwórczych o odpowiedniej jakości, minimalizowania wpływu fluktuacji czy tarć rynkowych. Dlatego też w jednostkach powiąza-

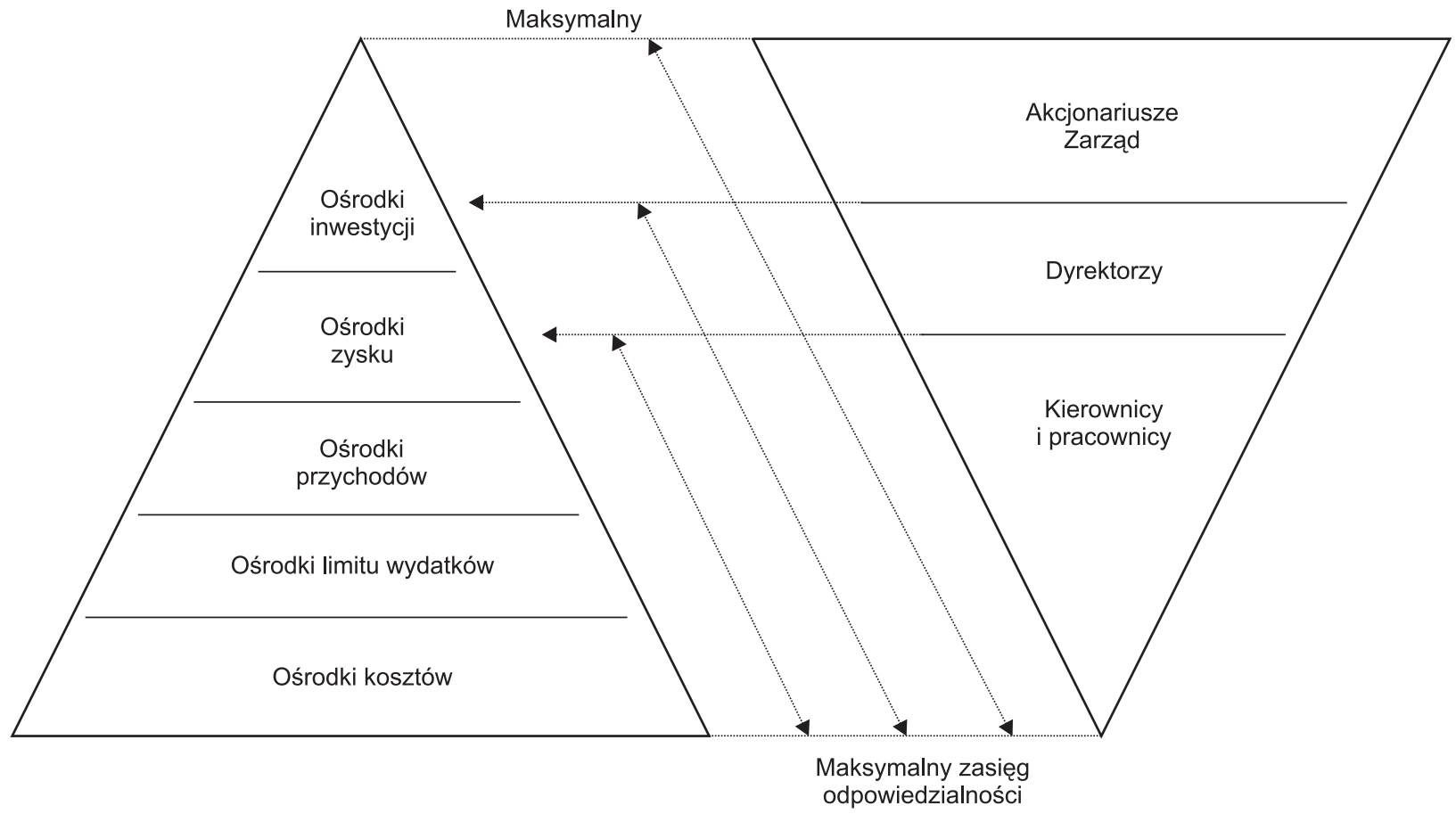

Rys. Hierarchia ośrodków i zakresu odpowiedzialności

Źródło: opracowanie własne na podstawie: D. HABELA, R. POLACZEK, Podstawy rachunkowości zarzadczej w przedsiębiorstwie, Wyższa Szkoła Komunikacji i Zarządzania, Poznań 2001, s. 67. 
nych lub o zdecentralizowanych strukturach zarzadzania część produktów (półfabrykatów) podlega wewnętrznej wymianie. Sprzedaż wewnętrzna, czyli nabywanie przez jedne podmioty wewnętrzne produktów innych podmiotów wewnętrznych, po określonych cenach, ma wpływ na poziom wyniku realizowanego przez ośrodki odpowiedzialności za zysk, jak również umożliwia zwiększenie wyniku finansowego całego przedsiębiorstwa.

Produkt, który jeden podmiot przekazuje drugiemu w ramach transakcji wewnętrznych, jest nazywany produktem przekazywanym lub produktem pośrednim, natomiast cena, po której to przekazanie następuje, to cena wewnętrzna, określana również jako cena transferowa ${ }^{13}$ ).

Stosowanie cen transferowych w sprzedaży wewnętrznej wynika z decentralizacji przedsiębiorstw. Jednocześnie przyczynia się do harmonijnej realizacji celów całego przedsiębiorstwa, jak i celów poszczególnych ośrodków odpowiedzialności. Największą korzyścią wynikającą ze stosowania tych cen jest możliwość dokonywania ocen działania ośrodków, a także, w szczególności, wspieranie podmiotów wewnątrz całej firmy w celu poprawy ich wyników finansowych, jak i pozostałych efektów (ilościowych i jakościowych) funkcjonowania całej firmy w konkurencyjnym otoczeniu.

Reasumując należy zauważyć, że podstawową korzyścią wynikającą z tworzenia centrów odpowiedzialności jest możliwość dokonywania oceny każdego kierownika (menedżera) odpowiadającego za dany obszar na podstawie efektów osiąganych przez jego ośrodek. Aby można było tego dokonać, każdy z ośrodków odpowiedzialności powinien mieć własny system planowania i obserwacji działalności, zawierający również rachunkowość. Rachunkowość prowadzona na użytek danego centrum odpowiedzialności jest określana mianem rachunkowości odpowiedzialności.

Rachunkowość odpowiedzialności jest innowacyjnym systemem finansowej oceny działalności segmentów przedsiębiorstwa. Polega ona na monitorowaniu działalności ośrodków w celu uzyskania wyspecjalizowanej informacji wspomagającej proces podejmowania decyzji. Pozyskane sygnały są odpowiednio przetwarzane, aby nadać im cechy informacji przydatnej w zarządzaniu. Opracowywane przez różne ośrodki odpowiedzialności raporty i meldunki są zatem generowane w zbiory, które stają się podstawą do określania przez zarządzających planów strategicznych, z uwzględnieniem zmiennych warunków otoczenia. Rezultaty monitorowania umożliwiają również wczesne reagowanie na pojawienie się zjawisk o charakterze destrukcyjnym, które niekorzystnie mogą wpływać na przebieg procesów gospodarczych, a nawet zagrażać dotychczasowej pozycji rynkowej firmy. Wdrożenie rachunkowości odpowiedzialności może w znaczący sposób przyczynić się do poprawy jakości procesu decyzyjnego i procedur delegowania uprawnień na niższe szczeble. W odpowiedni sposób zaprojektowana i zastosowana rachunkowość odpowiedzialności jest skutecznym narzędziem angażowania pracowników w realizację strategicznych celów organizacji. Zapewnia także odpowiednią kontrolę i motywację pracowników ${ }^{14)}$.
Racjonalne wyodrębnienie ośrodków odpowiedzialności wymusza często zmiany w strukturze organizacyjnej przedsiębiorstwa. Konieczne staje się wówczas zmodyfikowanie istniejącej, często tradycyjnej hierarchii zarządzania. Punktem wyjścia powinno być w szczególności dostosowanie przyjętego podziału na ośrodki odpowiedzialności do odpowiedniego przekroju rachunkowości prowadzonej w jednostce gospodarczej. Zaistnienie bowiem „zjawiska harmonii” pomiędzy systemem informacyjnym rachunkowości a odpowiednim obszarem decyzyjnym pozwoli na wykształcenie wzajemnie się zazębiających i tworzących logiczną całość, sprawnych i efektywnych obszarów informacyjno-decyzyjnych. Wykreowane w ten sposób struktury, gdzie każdy ośrodek podlega ciąłemu monitorowaniu, przyczynią się skutecznie do bardziej wiarygodnego i poprawnego przypisania odpowiedzialności menedżerowi oraz pozwolą na ocenę jego pracy na podstawie analizy wykonanych zadań. Jednocześnie ocena dokonywana przez zarząd przedsiębiorstwa będzie bardziej precyzyjna, co może mieć praktyczne przełożenie na adekwatny dobór systemu motywowania.

Warunkiem uzyskania pozytywnych wyników w organizacji zdecentralizowanej jest jednak gotowość dyrekcji do przekazania na niższe szczeble, obok odpowiedzialności, również odpowiednich uprawnień i niezbędnych kompetencji.

dr Magdalena Ossowska Uniwersytet Szczeciński Wydział Zarzadzania i Ekonomiki Usług

\section{PRZYPISY}

1) E. NOWAK, Rachunkowość zarzadcza, Wydawnictwo Profesjonalnej Szkoły Biznesu, Kraków 2001, s. 160.

2) Por.: Rachunek kosztów i rachunkowość zarzadcza. Najnowsze tendencje, procedury $i$ ich zastosowanie $w$ przedsiębiorstwach, red. I. SOBAŃSKA, C.H.BECK, Warszawa 2003 , s. 111.

3) W. GABRUSEWICZ, A. KAMELA-SOWIŃSKA, H. POETSCHKE, Rachunkowość zarzadcza, PWE, Warszawa 2001, s. 208.

4) Budżetowanie kosztów..., op.cit., 65.

5) Szerzej: E. NOWAK, Rachunkowość zarzqdcza..., op.cit., s. $28-31$.

6) Ibidem, s. 168.

7) W. GABRUSEWICZ, A. KAMELA-SOWIŃSKA, H. POETSCHKE, Rachunkowość zarzadcza..., op.cit., s. 208-209.

8) Por: Rachunek kosztów i rachunkowość..., op.cit., s. 112; W. GABRUSEWICZ, A. KAMELA-SOWIŃSKA, H. POETSCHKE, Rachunkowość zarzadcza..., op.cit., s. 209.

9) Rachunkowość zarzadcza. Wybrane zagadnienia..., op.cit., s. $126-127$.

10) E. NOWAK, Rachunkowość zarzadcza..., op.cit., s. 169.

11) Szerzej: Rachunkowość zarzadcza. Wybrane zagadnienia..., op.cit., s. 127; E. NOWAK, Rachunkowość zarzadcza..., op.cit., s. $172-176$.

12) Szerzej: S. NAHOTKO, S. AYYOUB, Budżetowanie operacyjne $i$ finansowe $w$ przedsiebiorstwie. Metody $i$ przyktady, Biblioteka Menedżera i Służby Pracowniczej, zeszyt 231, Oficyna Wydawnicza Ośrodka Postępu Organizacyjnego, Bydgoszcz 2002, s. 250.

13) Szerzej na temat cen transferowych: A.A. JARUGA, W. A. NOWAK, A. SZYCHTA, Rachunkowość zarzadcza..., op.cit., s. 483; Zarzadcze aspekty rachunkowości..., op.cit., s. 341; Rachunek kosztów i rachunkowość..., op.cit., s. $118-119$.

14) Ibidem, s. 391. 